\title{
Penguatan Kultur Literasi di Madrasah Berbasis Riset Melalui Optimalisasi Fungsi Perpustakaan di MTs Negeri 1 Kota Batu
}

\author{
${ }^{1}$ Muhammad Walid; ${ }^{2}$ Nurlaeli Fitriah; ${ }^{3}$ Luthfiya Fathi Pusposari \\ 1,2,3Universitas Islam Negeri Maulana Malik Ibrahim Malang, Indonesia \\ 1'walidpgmi@pgmi.uin-malang.ac.id; 2nurlaily.fitriah@uin-malang.ac.id; 3luthfiya@pips.uin- \\ malang.ac.id
}

\begin{abstract}
Gerakan Literasi Sekolah (GLS) is one of the government programs in order to regain reading interest in students. The meaning of literacy today is not merely meaning not being able to read, more than that literacy is related to understanding and sensitivity in relating it to life. Therefore the development of literacy is not only on the aspects of students but also all the components that can support the growth of literacy culture. The purpose of this study was to strengthen the literacy culture that had previously been built but was not optimal. Through mentoring, it is hoped that the culture built can be further strengthened by optimizing the function of the library as a learning resource. This article was written based on field studies in the form of dedication conducted at MTs Negeri 1 Kota Batu using ABCD aproach. The findings from the results of this study are that the optimization of library functions through workshops and capacity building activities for the library division team (komica) enriches their capacity as library ambassadors so that students who are members of the comica team more freely contribute to socializing library functions to colleagues other students in the MTs Negeri 1 Batu neighborhood by utilizing the IT capacity they obtain from workshops and capacity building activities.
\end{abstract}

Keyword. Library Function; Literacy Culture; Research Class.

Abstrak. Gerakan Literasi Sekolah (GLS) adalah salah satu program pemerintah dalam rangka menumbuhkan kembali minat baca terutama pada anak sekolah. Makna literasi saat ini bukan semata-mata bermakna melek huruf, lebih dari itu literasi berhubungan dengan pemahaman dan kepekaan dalam menghubungkannya dengan kehidupan. Oleh karena itu pengembangan literasi dapat berkembang tidak hanya pada aspek peserta didik tetapi juga seluruh komponen yang ada yang dapat mendukung tumbuhnya kultur literasi. Tujuan dari kajian ini adalah untuk menguatkan kultur literasi yang sebelumnya sudah dibangun namun belum optimal. Melalui pendampingan yang dilakukan diharapkan kultur yang terbangun dapat lebih diperkuat dengan mengoptimalkan fungsi perpustakaan sebagai sumber belajar. Artikel ini ditulis berdasarkan studi lapangan dalam bentuk pengabdian yang dilakukan di Madrasah Tsanawiyah 1 Kota Batu dengan menggunakan pendekatan Asset Based Community Driven (ABCD) yang berfokus pada potensi yang dimiliki dampingan. Temuan dari hasil studi ini adalah bahwa optimalisasi fungsi perpustakaan yang dilakukan melalui kegiatan-kegiatan workshop dan capacity building bagi tim divisi perpustakaan (komica) memperkaya kapasitas mereka sebagai duta perpustakaan sehingga siswa yang tergabung dalam tim komica ini lebih leluasa memberikan kontribusi sosialisasi fungsi perpustakaan kepada rekan siswa lainnya di lingkungan MTs Negeri 1 Batu dengan memanfaatkan kapasitas IT yang mereka peroleh dari kegiatan workshop dan capacity building.

Kata kunci. Fungsi Perpustakaan; Kultur Literasi; Kelas Riset.

Copyright (C) J-PAI: Jurnal Pendidikan Agama Islam. All Right Reserved.

This is an open-access article under the CC BY-SA license

(https://creativecommons.org/licenses/by-sa/4.0/).

Correspondence Address: jpai@uin-malang.ac.id 
Muhammad Walid, dkk.: Penguatan Kultur Literasi di Madrasah Berbasis Riset...

\section{A. PENDAHUluAN}

Semangat literasi saat ini menjadi sebuah topik hangat yang banyak dibicarakan dan digalakkan dalam berbagai kegiatan seperti seminar, kuliah umum, sarasehan, talk show, dan kegiatan-kegiatan lainnya baik yang bersifat formal maupun non formal. Hal ini berangkat dari keprihatinan terhadap menurunnya minat baca anak bangsa. Hasil penelitian yang dilakukan oleh Most Littered Nation in the World tahun 2016 bahwa minat baca anak Indonesia berada pada posisi 60 dari 61 negara. Menurut Subekti Makdriani, Pustakawan Perpustakaan Republik Indonesia, salah satu factor yang mempengaruhi menurunnya minat baca ini adalah semakin berkembangnya teknologi terutama teknologi komunikasi digital (Suciatiningrum, 2017).

Literasi sering diartikan dengan melek huruf. Tentu saja ini berhubungan dengan kegiatan membaca. Hal ini sama sekali tidak salah. Namun dengan berkembangnya ilmu dan teknologi, makna literasi pun semakin berkembang dari waktu ke waktu. Selain membaca dan menulis, di dalam literasi terdapat kegiatan pembelajaran yang memungkinkan individu mencapai tujuannya, mengembangkan pengetahuan dan potensinya serta berpartisipasi dalam komunitas masyarakat (UNESCO 2005)

Bahkan Kern (2000) mendefinisikan literasi secara luas yaitu:

"Literacy is the use of socially-and historically-, and culturally situated practices

of creating and interpreting meaning through texts."

Kern (2000) berpendapat bahwa literasi tidak hanya melibatkan aspek kognitif yang berhubungan dengan kemampuan tekstual, tetapi juga melibatkan pemahaman dan kepekaan dalam menghubungkan penggunaannya dengan konteks kehidupan. Begitu luasnya makna literasi terutama di zaman digital ini yang memerlukan kepekaan masyarakat untuk memberikan iklim yang sesuai dengan perkembangan jaman dan perkembangan peserta didik agar kesadaran literasi tetap terjaga dari generasi ke generasi.

Pemerintah sebagai pemegang kebijakan dalam segala bidang, dalam hal ini pendidikan sebagai bentuk kesadaran akan pentingnya literasi menerapkan Gerakan Literasi Sekolah (GLS) dalam salah satu programnya. Adapun tahap pelaksanaan gerakan literasi sekolah (Wiedarti, 2016):

1. Pembiasaan dengan Menumbuhkan minat baca (sebelum pelajaran 15 menit membaca, serta meningkatkan kemampuan literasi melalui kegiatan menanggapi buku pengayaan.

2. Pengembangan: Pengembangan kemampuan literasi melalui kegiatan di perpustakaan sekolah/perpustakaan kota/ daerah atau taman bacaan masyarakat atau sudut baca kelas dengan berbagai kegiatan, antara lain: 1) membacakan buku dengan nyaring, membaca dalam hati membaca bersama (shared reading), membaca terpandu (guided reading), menonton film pendek, dan/atau membaca teks visual/digital (materi dari internet); 2) peserta didik merespon teks (cetak/visual/digital), fiksi dan nonfiksi, melalui beberapa kegiatan sederhana seperti menggambar, membuat peta konsep, berdiskusi, dan berbincang tentang buku.

3. Pembelajaran: meningkatkan kemampuan literasi di semua mata pelajaran menggunakan buku pengayaan dan strategi membaca di semua mata pelajaran

Dunia akademik pun berkontribusi dalam menumbuhkan kembali kesadaran literasi di kalangan generasi muda. Sulistyowati dalam artikelnya tentang penguatan budaya literasi mengembangkan budaya literasi pada siswa melalui pembelajaran berbasis proyek (Sulistyowati, 2016). Pembelajaran yang diberikan mampu meningkatkan penguatan budaya literasi pada siswa.

Sebagai bagian dari unsur penunjang dalam penyelenggaraan pendidikan di sekolah maupun perguruan tinggi adalah perpustakaan sekolah dan perpustakaan PT. 
Perpustakaan sekolah adalah bagian penting dalam lembaga pendidikan sekolah karena merupakan pusat informasi dan tempat terkumpulnya sumber ilmu pengetahuan.

Sumpeno menyatakan bahwa perpustakaan sekolah memiliki fungsi: 1) informasi, 2) pendidikan, 3) administrasi, 4) pendidikan, 5) rekreatif, 6) social dan 7) riset (Supriyanto \& Muhsin, 2008). Melalui fungsi ini diharapkan perpustakaan dapat membantu siswa dan guru dalam mengembangkan wawasan keilmuannya. Namun tak jarang fungsi perpustakaan tidak berjalan optimal karena pemanfaatannya hanya sebatas pinjam meminjam buku. Melalui kegiatan pengabdian yang dilakukan diharapkan fungsi perpustakan dapat dimanfaatkan secara optimal yang pada akhirnya akan memberikan iklim yang dapat menumbuhkan kultur literasi pada siswa

Madrasah Tsanawiyah Negeri I Batu adalah salah satu madrasah di kota Batu yang merupakan madrasah rintisan berbasis riset. Dari sekian madrasah/sekolah di Indonesia, MTsN I Batu terpilih sebagai salah satu madrasah yang dirintis menjadi madrasah berbasis riset. Untuk menunjang program tersebut, kepala madrasah berupaya untuk melakukan pembenahan-pembenahan. Salah satu upaya yang dilakukan adalah dengan mengoptimalkan fungsi perpustakaan. Peningkatan kompetensi sumber daya manusia dengan mendukung serta memotivasi pengelola perpustakaan MTsN I Batu mengikuti berbagai pelatihan kepustakaan. Salah satunya adalah mendaftar sebagai peserta pelatihan kepustakaan yang diselenggarakan oleh Pusdiklat Perpustakaan Nasional dan lolos seleksi 30 besar angkatan X pada Agustus 2017.

Namun upaya tersebut belum cukup optimal bagi madrasah dalam rangka menuju madrasah berbasis riset melalui fungsi perpustakaan. Meskipun pengelola perpustakaan dalam hal keilmuan telah mumpuni namun keterbatasan sumber daya manusia dalam pengelolaan perpustakaan dalam mengoptimalkan fungsinya menjadi salah satu permasalahan penting. Bagaimanapun juga perpustakaan dapat menjadi bahan rujukan dalam menggali informasi dan keilmuan serta menggali ide-ide meneliti bagi seluruh warga sekolah.

\section{B. METODE PENELITIAN}

Kegiatan yang akan dilakukan menggunakan pendekatan Asset Based Community Driven (ABCD) yang berfokus pada potensi yang dimiliki oleh masyarakat dampingan. Pendekatan ini digunakan dalam kegiatan pengabdian ini karena karakternya yang berbeda dengan pendekatan lainnya. Karakter utama dari pendekatan ini adalah bahwa pemberdayaan dapat dilakukan dengan lebih memberikan perhatian pada potensi atau kelebihan yang dimiliki oleh dampingan itu sendiri. Berbekal asset yang dimiliki, dampingan didorong untuk mengembangkan potensi yang sudah ada. Tim pengabdi memberikan penguatan dan bersama-sama mengelola potensi yang memang sudah dimiliki. Menurut Johnson Butterfield, Yeneabat, \& Moxley, bahwa setiap orang memiliki kapasitas, kemampuan dan bakat (Butterfield \& Korazim-Körösy, 2013).

Beberapa tahapan dalam pendekatan ABCD yang dilakukan meliputi 5 tahap yaitu : 1) melakukan diskusi dengan pengelola perpustakan untuk menemukan dan menggali potensi (dicovery), 2) selain menemukan potensi, dalam diskusi juga digali apa yang menjadi harapan dampingan dengan potensi yang dimiliki (dream), 3) tahapan selanjutnya tim menyusun strategi pelaksanaan (design), 4) menentukan kegiatan-kegiatan yang akan dilakukan bersama dengan dampingan (define), 5) dan kemudian melaksanakan kegiatan sesuai kesepakatan dengan dampingan (destiny).

Masyarakat yang dituju dalam pendampingan ini adalah masyarakat sekolah. Tepatnya masyarakat sekolah di MTs Negeri 1 Kota Batu. Oleh karena objek pendampingan adalah perpustakaan madrasah maka yang menjadi subjek utama pendampingan ini adalah siswa yang tergabung dalam divisi perpustakaan sebagai duta perpustakaan. Pada MTs Negeri 1 Kota Batu duta perpustakaan ini diberi nama tim komica (komunitas minat baca) 
Muhammad Walid, dkk.: Penguatan Kultur Literasi di Madrasah Berbasis Riset...

Subjek lainnya untuk mendukung keberhasilan pendampingan adalah kelas riset dan para guru. Kelas riset dalam pendampingan adalah kelas yang dibentuk oleh sekolah dalam program rintisan menuju sekolah berbasis riset. Kelas riset ini berfungsi sebagai pengguna perpustakaan. Keterlibatan kelas riset dalam pendampingan ini adalah untuk memantau sejauh mana pemanfaatan perpustakaan oleh siswa dalam menggali teori-teori yang relevan dengan kajian riset yang mereka lakukan.

Keterlibatan guru sebagai subjek dampingan dalam pendampingan ini adalah untuk membimbing siswa kelas riset dalam kegiatan risetnya. Untuk mendukung kemampuan guru maka diberikan penguatan metodologi riset.

\section{HASIL DAN PEMBAHASAN}

Salah satu indikator untuk mengetahui kemajuan suatu bangsa dapat dilihat melalui budaya membaca. Membaca adalah bagian dari kegiatan belajar, dan belajar identik dengan membaca. Dapat dikatakan belajar dan membaca memiliki hubungan yang saling mempengaruhi karena dengan membaca pengetahuan akan bertambah dan "tanpa membaca pendidikan bagai ruh tanpa raga". Dalam al-Qur'an hal tersebut jelas sekali disebutkan bahwa membaca adalah sebuah perintah. Membaca merupakan ajaran islam pertama yang dibawa malaikat Jibril kepada Muhammad SAW. Perintah membaca ini begitu penting hingga menjadi ajaran pertama yang dibawa malaikat Jibril agar dapat membuka wawasan berpikir manusia, meningkatkan kemampuan intelektual dan berpikir kritis terhadap segala yang ada di muka bumi ini.

Untuk dapat memahami dunia, seorang manusia mesti membaca. Sehingga tidak salah jika dikatakan bahwa membaca adalah gerbang peradaban bangsa. Tingkat kemajuan sebuah bangsa biasanya berbanding lurus dengan kemampuan membaca suatu bangsa (Munawar \& Rahman, 2012). Karena dengan membaca orang dapat menjelajahi dunia dan mengetahui informasi tentang berbagai pengalaman pengetahuan manusia sepanjang sejarahnya. Dengan pengetahuan yang diperolehnya orang akan merekayasa, mencipta, mengkritisi sehingga diperoleh hasil yang akan memberikan sumbangan kemajuan pada dunia.

Membaca memang tidak harus selalu buku, dapat berupa majalah, surat kabar atau media cetak lainnya, atau pun berupa media informasi dan teknologi. Apapun media yang digunakan dalam membaca asalkan memberi kontribusi peningkatan kualitas pengetahuan seseorang tidak menjadi masalah. Yang menjadi masalah adalah ketika keinginan membaca itu berangsur-angsur mengalami penurunan atau bahkan hilang. Oleh karena itu perlu dijaga agar iklim atau budaya membaca itu tetap ada pada diri kita terutama pada generasi bangsa atau peserta didik di sekolah.

Tempat yang paling representatif dalam mengembangkan kapasitas pengetahuan dan menyalurkan minat baca adalah perpustakaan. Dalam rangka menyalurkan minat baca, perpustakaan ada di mana saja. Baik di lingkungan formal maupun di lingkungan non formal dan informal. Di lingkungan formal pendidikan dikenal dengan perpustakaan sekolah. Sebagai bagian dari unsur penunjang dalam penyelenggaraan pendidikan di sekolah maupun perguruan tinggi adalah perpustakaan sekolah dan perpustakaan PT. Perpustakaan sekolah adalah bagian penting dalam lembaga pendidikan sekolah karena merupakan pusat informasi dan tempat terkumpulnya sumber ilmu pengetahuan.

Sumpeno menyatakan bahwa perpustakaan sekolah memiliki fungsi: 1) informasi, 2) pendidikan, 3) administrasi, 4) pendidikan, 5) rekreatif, 6) social dan 7) riset (Supriyanto \& Muhsin, 2008). Melalui fungsi ini diharapkan perpustakaan dapat membantu siswa dan guru dalam mengembangkan wawasan keilmuannya. Namun tak jarang fungsi perpustakaan tidak berjalan optimal karena pemanfaatannya hanya sebatas pinjam meminjam buku. Melalui kegiatan pengabdian yang dilakukan diharapkan fungsi 
perpustakan dapat dimanfaatkan secara optimal yang pada akhirnya akan memberikan iklim yang dapat menumbuhkan kultur literasi pada siswa.

Sebagaimana halnya sekolah lainnya, penyelenggaraan perpustakaan pada MTsN Batu memiliki tujuan yang ingin dicapai di antaranya;

a) memberikan kesempatan kepada siswa untuk menggunakan bahan pustaka dalam meningkatkan pengetahuan dan keterampilan;

b) Menyediakan informasi yang murah, mudah, cepat dan tepat yang berguna bagi siswa;

c) Membantu dalam pengembangan dan pemberdayaan komunitas melalui penyediaan bahan pustaka dan informasi misalnya komunitas komika dan komunitas kelas riset;

d) Bertindak selaku agen cultural, sehingga menjadi pusat utama kehidupan budaya bagi siswa;

e) Memfasilitasi siswa dan masyarakat sekitar untuk belajar sepanjang hayat.

f) Membantu siswa untuk mengembangkan kemampuan yang dimilikinya sehingga yang bersangkutan akan bermanfaat bagi masyarakat sekitarnya, sejauh kemampuan tersebut dapat dikembangkan dengan bantuan bahan pustaka.

Sedangkan tugas dan fungsi Perpustakaan di MTsN adalah:

a) Fungsi Edukatif; Perpustakaan madrasah menyediakan berbagai jenis bahan bacaan berupa karya cetak dan karya rekam untuk dapat dijadikan sumber belajar dan menambah pengetahuan siswa secara mandiri.

b) Fungsi Informatif; Perpustakaan madrasah sama dengan berbagai jenis perpustakaan lainnya, yaitu menyediakan buku-buku referensi, bacaan ilmiah popular berupa buku dan majalah ilmiah serta data-data penting lainnya yang di perlukan pembaca.

c) Fungsi Kultural; Perpustakaan madrasah menyediakan berbagai bahan pustaka sebagai hasil budaya bangsa yang direkam dalam bentuk tercetak/terekam. Perpustakaan madrasah merupakan tempat penyimpanan dan terkumpulnya berbagai karya budaya manusia yang setiap waktu dapat diikuti perkembangannya melalui koleksi perpustakaan.

d) Fungsi Rekreasi; Perpustakaan madrasah bukan hanya menyediakan bacaan-bacaan ilmiah, tetapi juga menghimpun bacaan hiburan berupa buku-buku fiksi dan majalah hiburan untuk anak-anak, remaja dan dewasa. Bacaan fiksi dapat menambah pengalaman atau menumbuhkan imajinasi pembacanya dan banyak digemari oleh para siswa.

e) Fungsi Riset; Perpustakaan madrasah berfungsi sebagai objek dan subyek serta penyedia segala fasilitas yang dibutuhkan untuk pelaksanaan riset di madrasah

Adapun pengelolaan perpustakaan di MTsN Batu bukan sekedar kegiatan menempatkan buku-buku di rak, akan tetapi lebih dari itu, sangat kompleks, berkelanjutan, dan selalu berubah. Beberapa faktor yang dapat ditemui dalam sebuah proses mengelola perpustakaan madrasah diantaranya adalah: 1) Kebijakan dan prosedur; 2) Mengelola Koleksi; 3) Pendanaan dan Pengadaan; 4) Mengelola Fasilitas; 5) Sumber Daya Manusia 6) Perencanaan.

Kegiatan mengelola bagi pengelola perpustakaan (guru-pustakawan), merupakan bagian atau peran serta dalam pendidikan di sekolah. Secara efektif perpustakaan harus mampu mendukung kurikulum dan program-program sekolah. Untuk mewujudkan mengelola perpustakaan yang baik, maka pengelola perpustakaan di MTsN Batu telah:

a) Mengembangkan kemampuan professional sebagai guru-pustakawan;

b) Memperhatikan kemampuan yang diperlukan dan prosedur yang dibutuhkan untuk dapat mengelola perpustakaan secara efektif, dari perpustakaan yang sekedar bertahan hidup menjadi perpustakaan yang benar-benar berjalan secara baik;

c) Mengembangkan kebijakan dan prosedur dengan prinsip-prinsip yang mengaktualisasikan visi dari perpustakaan madrasah. 
Muhammad Walid, dkk.: Penguatan Kultur Literasi di Madrasah Berbasis Riset...

d) Memperlihatkan keterkaitan antara sumber-sumber informasi dan tujuan dan prioritas madrasah, serta program perpustakaan;

e) Menunjukkan peran guru-pustakawan melalui rencana mengelola perpustakaan.

Tidak cukup hanya sekedar peran pimpinan lembaga dan pengelola perpustakaan. Dalam rangka untuk menumbuhkan kultur literasi melalui optimalisasi fungsi perpustakaan ini diperlukan berbagai upaya. Pendampingan yang dilakukan untuk mendukung penguatan kultur literasi melalui optimalisasi fungsi perpustakaan antara lain: 1) meningkatkan keterlibatan peserta didik dalam pengelolaan perpustakaan, 2) membangun kesadaran pentingnya perpustakaan sekolah sebagai bagian penting dalam kegiatan pembelajaran terutama yang berkaitan dengan riset, 3) menguatkan kemampuan metodologi guru agar mampu membimbing siswa dalam kegiatan penulisan karya ilmiah dan memanfaatkan perpustakaan dengan optimal dalam mendukung kegiatan pembelajaran.

a. Keterlibatan siswa dalam pengelolaan perpustakaan

Upaya ini menjadi penting dalam pengelolaan perpustakaan karena fungsi yang ada di dalamnya dapat berjalan dengan baik. Keterlibatan peserta didik dalam menjalankan fungsi perpustakaan pada pendampingan ini adalah melalui pelibatan aktif para siswa dalam tim komica. Tim komica ini merupakan tim yang dibentuk oleh pengelola perpustakaan dengan merekrut para siswa untuk menjadi duta perpustakaan. Tugas dan fungsi mereka adalah selain membantu pengelola perpustakaan dalam kegiatan administrasi di perpustakaan, mereka juga membantu mensosialisasikan fungsi perpustakaan kepada rekan siswa lainnya.

Melalui siswa upaya menggiatkan aktivitas perpustakaan akan lebih efektif. Dengan keterlibatan siswa akan menumbuhkan rasa memiliki dan mencintai perpustakaan. Selain itu siswa akan memberi pengaruh positif terhadap teman sebayanya dalam upaya mengenalkan fungsi perpustakaan. Telah banyak penelitian yang membuktikan bahwa pengaruh teman sebaya sangat besar terhadap perkembangan remaja. aspek budaya teman sebaya (behavioral peer culture) terkait dengan pencapaian individu sementara komponen budaya teman sebaya relasional dan perilaku terkait dengan sekolah (Brown, 1982; Clasen \& Brown, 1985; Lynch, Lerner, \& Leventhal, 2013). Baik pengaruh positif maupun negatif. Oleh karena itu, memanfaatkan sisi positif dari pengaruh teman sebaya akan sangat menguntungkan.

Rekruitmen siswa dalam kegiatan kepustakaan dengan menugaskan mereka dalam divisi perpustakaan dapat dilakukan melalui tugas-tugas pelayanan, sosialisasi, desain ruang dan sebagainya. Tentu saja dengan tidak mengganggu waktu belajar siswa. Sejak tahun 2017 siswa MTsN Batu yang terlibat dalam tim komika mencapai 34 siswa, 46\% berjenis kelamin perempuan dan $54 \%$ berjenis kelamin laki-laki.

Awalnya para siswa yang tergabung dalam tim komica ini lebih banyak berperan dalam kegiatan di dalam perpustakaan. Namun lambat laun mereka lebih mendalami tugas sosialisasi yang mereka emban. Terutama ketika tim pengabdi mendampingi mereka dalam meningkatkan kapasitas mereka dalam kegiatan capacity building. Siswa yang menjadi duta perpustakaan tentu masih awam akan tugasnya di perpustakaan. Oleh karena itu perlu pendampingan agar fungsinya sebagai duta perpustakaan dapat terarah dan terlaksana dengan baik sesuai dengan bakat dan minatnya. Kegiatan ini terbagi dalam beberapa sesi yaitu sesi workshop untuk meningkatkan kapasitas IT yang telah mereka miliki agar lebih leluasa dalam melakukan sosialisasi fungsi perpustakan dan kegiatan outbond untuk meningkatkan semangat dan kerjasama tim yang baik di antara mereka.

Kegiatan tersebut di atas dipilih dengan pertimbangan bahwa siswa kita saat ini adalah generasi milenial yakni generasi yang sangat dekat dengan kemajuan teknologi informasi. Siswa saat ini telah terbiasa dengan keberadaan gadget. Gadget sebagai bagian 
kemajuan teknologi untuk memudahkan komunikasi antar individu secara global. Media online banyak menjadi kecenderungan para siswa dalam berkomunikasi. Pengelola perpustakaan perlu untuk menangkap gejala itu dan memanfaatkannya.

Pendampingan yang dilakukan kepada tim komika adalah dengan memberikan pelatihan desain media sosialisasi menggunakan berbagai aplikasi. Ada beberapa aplikasi android yang dapat digunakan dalam literasi di antaranya Unfold (dapat digunakan untuk membuat quote), InShoot (dapat digunakan untuk qoutes berupa video atau foto), Zeotropik (untuk efek misalnya mendung yang berjalan di foto). Pelatihan ini menghasilkan beberapa quotes baik yang berbentuk video maupun foto. Produk yang dihasilkan dalam bentuk software ini dipublikasikan oleh siswa melalui media online. Media online sebagai media publikasi dan promosi perpustakaan yang dimanfaatkan oleh siswa antara lain Instagram, Facebook, whatsapp, dan lain-lain.

Kegiatan yang dapat dilakukan lainnya adalah siswa dilibatkan dalam mendesain perpustakaan. Meskipun siswa tidak sepenuhnya memberi ide desain yang baik namun pengelola perpustakaan dapat melibatkan mereka dalam penataannya. Misalnya menata pojok baca atau gang baca. Di MTs Negeri 1 Kota Batu pojok baca awalnya diletakkan di lantai 2 depan perpustakaan. Kemudian perpustakaan berpindah di lantai 1 dengan pertimbangan jika di lantai 1 akan mudah dijangkau oleh sivitas akademika. Dan pojok baca tetap diletakkan di depan perpustakaan.

Selain itu dikembangkan pula gang baca dengan memanfaatkan tempat yang tak terpakai namun menjadi tempat yang sering dilalui siswa. Gang baca ini memiliki fungsi yang sama dengan pojok baca. Penataan yang dilakukan dibuat semenarik mungkin agar siswa senang dan nyaman untuk singgah dan membaca di tempat tersebut. Gang baca dilengkapi dengan rak-rak buku kecil yang diisi dengan buku-buku bacaan ringan.

b. Menumbuhkan Kesadaran Pentingnya Fungsi Perpustakaan dalam Kegiatan Riset

Remaja diartikan sebagai masa perkembangan transisi antara masa anak dan masa dewasa yang mencakup perubahan biologis, kognitif dan social emosional. Pada kebanyakan budaya, remaja dimulai pada kira-kira usia 10 - 13 tahun dan berakhir kirakira pada usia 18-20 tahun (Santrock, 2003).

Pada masa ini remaja telah berpikir abstrak dan logis. Piaget mengkategorikan remaja pada tahap operasional formal bahwa remaja memiliki kemampuan menyusun hipotesis (Santrock, 2003). Remaja mulai berpikir seperti ilmuwan, mereka dapat menyusun rencana-rencana untuk memecahkan permasalahan dan menguji masalah secara sistematis. Yang perlu dilakukan adalah memotivasi mereka menyadari kemampuan/potensi yang dimilikinya. Pemberian motivasi dapat dilakukan dengan berbagai cara, salah satunya melalui kegiatan seminar bertema motivasi.

Kegiatan seminar dalam rangka meningkatkan kemampuan meneliti yang dilakukan di MTs Negeri 1 Batu dilaksanakan dalam 2 sesi kegiatan. Kegiatan ini ditujukan bagi siswa di kelas riset. Kelas riset di MTs Negeri 1 Kota Batu dibentuk dalam rangka merintis menjadi madrasah berbasis riset. Untuk meningkatkan motivasi dan kemampuan meneliti siswa diperkenalkan dengan berbagai contoh-contoh tema penelitian yang cocok untuk siswa.

Materi seminar yang bermuatan motivasi meneliti ini juga menyampaikan betapa pentingnya teori sebagai landasan berpikir dan membantu para peneliti dalam menjawab pertanyaan penelitian. Dalam seminar tersebut disampaikan pula bahwa salah satu tempat yang cocok bagi peneliti dalam menggali teori adalah perpustakaan.

Sebagaiamana telah disampaikan sebelumnya, usia remaja telah pada tahap di mana mereka telah mampu bepikir seperti ilmuwan. Kesadaran akan potensi berpikir remaja inilah menginspirasi munculnya berbagai klub riset remaja di dunia. Youth Science Club (YSC) adalah klub peneliti remaja (usia 12-18 tahun) yang dibentuk oleh UNESCO pada 
Muhammad Walid, dkk.: Penguatan Kultur Literasi di Madrasah Berbasis Riset...

tahun 1963. Pada tahun 1970 batasan usia tersebut diubah menjadi 12-21 tahun. Di Indonesia sendiri, YSC dikenal dengan sebutan Kelompok Ilmiah Remaja (KIR) atas inisiatif remaja Indonesia sendiri. KIR sebenarnya adalah perkembangan dari Remaja Yudha Club (RYC) yang dibentuk oleh Koran Harian Berita Yudha pada tahun 1969. Setelah difasilitasi oleh LIPI, RYC berkembang menjadi KIR yang dilaksanakan di berbagai sekolah di seluruh Indonesia

Remaja jaman old sudah memulai gerakan riset remaja. Remaja jaman now dengan kemajuan teknologi yang sangat pesat mestinya lebih berpeluang untuk ikut andil dalam perkembangan ilmu pengetahuan.

Namun terkadang menjadi seorang peneliti dianggap sebagai sesuatu yang tidak mudah karena dibutuhkan kemampuan menulis yang baik. Dalam seminar yang diberikan disampaikan tips-tips menulis karya ilmiah dan menemukan tema meneliti.

Disampaikan pula bahwa untuk dapat menulis yang baik perlu banyak membaca. Membaca tidak harus buku teks, apapun bacaannya dapat memberikan inspirasi dalam meneliti. Yang penting adalah membangun minat dalam membaca. Kalau suka membaca biasanya pengetahuannya akan bertambah. Semakin banyak yang dibaca semakin banyak yang ingin diketahuinya karena manusia itu senang membandingkan apa yang dia baca dan dialaminya. Itu namanya kritis. Manusia juga dianugerahkan kemampuan untuk mengolah otaknya untuk memunculkan ide. Itu namanya kreatif. Kreativitas bukan tentang bakat. Kreativitas berhubungan dengan logika, persepsi, emosi, perasaan dan naluri (de Bono, 2007). Agar kreatifitas itu muncul tentu harus banyak membaca, peka dengan apa yang ada di sekitar dan mengkritisi apa yang dibaca dan apa yang dialami.

Kegiatan ini dapat membuka wawasan dan mindset para siswa akan pentingnya membaca untuk menggali teori yang akan mendukung riset yang akan dilakukan. Dari kegiatan ini juga bermunculan ide-ide kreatif siswa dalam bentuk tema yang mungkin untuk mereka kaji sesuai dengan karakteristik dan usia mereka seperti mengapa penggunaan micin berbahaya bagi kesehatan, pengaruh bacaan ayat-ayat al-qur'an terhadap pertumbuhan jamur tiram, faktor penyebab mobile legend game disukai anakanak, dan masih bayak tema penelitian lainnya.

c. Kontribusi Pendidik sebagai Pembimbing Siswa

Cita-cita mewujudkan tumbuhnya kultur literasi di MTs Negeri 1 Kota Batu telah lama dilakukan. Hal ini dalam rangka untuk memenuhi 8 standar yang di tetapkan permerintah yang di dalamnya ternasuk kultur literasi. Kultur literasi akan terbangun tentu tidak terlepas dari peran seluruh warga yang ada di madrasah. Para pimpinan di madrasah, guru dan juga siswa.

Dalam pendampingan yang dilakukan, upaya yang dilakukan tidak hanya meningkatkan keterlibatan siswa dalam kegiatan yang berhubungan dengan penguatan kultur literasi di sekolah. Untuk melengkapi kegiatan pendampingan ini, guru juga diberikan penguatan metodologi riset. Kegiatan ini dilakukan untuk merefresh kemampuan riset guru sehingga mampu membimbing siswa dalam kegiatan riset dan mampu mengarahkan siswa mengolah informasi yang siswa peroleh dari berbagai sumber yang dibaca.

Kegiatan penguatan kemampuan riset pada guru memberikan kontribusi yang secara tidak langsung bagi penguatan kultur literasi di MTs Negeri 1 Kota Batu. Dikatakan demikian karena beberapa guru telah ikut membimbing siswa dalam mengembangkan riset terutama bagi siswa di kelas riset. Beberapa hasil riset yang dihasilkan oleh siswa pada kelas riset tersebut misalnya pengembangan produk berupa: 1) Selimut Ettawa berhasil mendapat medali perunggu Kompetisi Olimpiade Peneliti Siswa Indonesia - OPSI 2018 tingkat Nasional; 2) Komik Kebhinekaan sebagai penanaman Jiwa Nasionalisme mendapat medali Perunggu dalam MYRES 2018; 3) Magic Ice Peringkat 4 MYRES 2019 
Kegiatan riset memang diperlukan pengalaman yang tidak hanya diperoleh di lapangan tetapi juga melalui referensi-referensi yang diperoleh dari berbagai sumber baik dari buku, majalah, koran, surat kabar dan lain-lain. Kalau suka membaca, maka pengetahuannya akan bertambah. Semakin banyak yang dibaca semakin banyak yang ingin diketahuinya.

\section{KESIMPULAN}

Upaya mendukung penguatan kultur literasi melalui optimalisasi fungsi perpustakaan dilakukan melalui kegiatan-kegiatan antara lain: 1) meningkatkan keterlibatan peserta didik dalam pengelolaan perpustakaan, 2) membangun kesadaran pentingnya perpustakaan sekolah sebagai bagian penting dalam kegiatan pembelajaran terutama yang berkaitan dengan riset, 3) menguatkan kemampuan metodologi guru agar mampu membimbing siswa da lam kegiatan penulisan karya ilmiah dan memanfaatkan perpustakaan dengan optimal dalam mendukung kegiatan pembelajaran.

Kegiatan pelatihan yang diberikan kepada siswa ini dilakukan untuk menumbuhkan motivasi dan capacity building siswa sehingga mereka mengetahui peran yang diembannya sebagai duta perpustakaan. Kegiatan ini menghasilkan beberapa produk berupa quotes baik yang berbentuk video maupun foto yang kemudian dipublikasikan melalui media sosial online.

Untuk menunjang kegiatan yang dilakukan di atas, pendampingan juga dilakukan kepada siswa lainnya sebagai pengguna perpustakaan. Dalam hal ini siswa kelas riset. Materi seminar yang bermuatan motivasi meneliti ini juga menyampaikan betapa pentingnya teori sebagai landasan berpikir dan membantu para peneliti dalam menjawab pertanyaan penelitian. Kegiatan ini dapat membuka wawasan dan mindset para siswa akan pentingnya membaca untuk menggali teori yang akan mendukung riset yang akan dilakukan. Dari kegiatan ini juga bermunculan ide-ide kreatif siswa dalam bentuk tema yang mungkin untuk mereka kaji sesuai dengan karakteristik dan usia mereka.

Kegiatan penguatan kemampuan riset pada guru memberikan kontribusi yang secara tidak langsung bagi penguatan kultur literasi di MTs Negeri 1 Kota Batu. Dikatakan demikian karena beberapa guru telah ikut membimbing siswa dalam mengembangkan riset terutama bagi siswa di kelas riset

\section{DAFTAR PUSTAKA}

Brown, B. B. (1982). The extent and effects of peer pressure among high school students: A retrospective analysis. Journal of Youth and Adolescence, 11(2), 121-133. https://doi.org/10.1007/BF01834708

Butterfield, A. K. J., \& Korazim-Körösy, Y. (2013). Interdisciplinary Community Development: International Perspectives. Routledge.

Clasen, D. R., \& Brown, B. B. (1985). The multidimensionality of peer pressure in adolescence. Journal of Youth and Adolescence, 14(6), 451-468. https://doi.org/10.1007/BF02139520

de Bono, E. (2007). Revolusi Beripikir. PT Mizan Publika.

Kern, R. (2000). Literacy and language teaching. New York: Oxford University Press.

Lynch, A. D., Lerner, R. M., \& Leventhal, T. (2013). Adolescent Academic Achievement and School Engagement: An Examination of the Role of School-Wide Peer Culture. Journal of Youth and Adolescence, 42(1), 6-19. https://doi.org/10.1007/s10964012-9833-0

Munawar, B. M. \&, \& Rahman. (2012). Ensiklopedi Nurcholish Madjid (Jilid-3)-Pemikiran Islam di Kanvas Peradaban, Democracy Project. Jakarta: Mizan.

Santrock, J. W. (2003). Adolescence, edisi 6. Jakarta: Erlangga. 
Muhammad Walid, dkk.: Penguatan Kultur Literasi di Madrasah Berbasis Riset...

Suciatiningrum, D. (2017, Mei). Memprihatinkan, Ternyata Minat Baca Indonesia Duduki Peringkat 60 dari 61 Negara. Tribunnews.com. Retrieved from https://www.tribunnews.com/regional/2017/05/15/memprihatinkan-ternyataminat-baca-indonesia-duduki-peringkat-60-dari-61-negara

Supriyanto, W., \& Muhsin, A. (2008). Teknologi Informasi Perpustakaan. Kanisius.

Wiedarti, P. (2016). Desain induk gerakan literasi sekolah. Jakarta: Direktorat Jenderal Pendidikan Dasar dan Menengah. 